\title{
SCIREA
}

Volume 6, Issue 2, April 2021

\section{Effect of Social Economic Status and Economic Racionality On Learing Outcome in Hight School}

\author{
Mashudi,", Aminiyati', Riama Al Hidayah', Erwin sutandar ${ }^{2}$ \\ ${ }^{1}$ Faculty of Teacher Training and Education, Tanjungpura University, West Kalimantan, \\ Indonesia \\ ${ }^{2}$ Faculty of civil engineering, Tanjungpura University, West Kalimantan, Indonesia \\ *Corresponding author
}

Email: profdrmashudi@gmail.com (Mashudi); Erwin_sutandar@yahoo.com (Erwin sutandar)

\begin{abstract}
The research objective was to analyze the influence of socio-economic status, economic rationality on the learning outcomes of students

The socioeconomic status of the parents of students is very large in determining the learning outcomes of students. The economic rationality of students will affect the acquisition of learning outcomes

The problem is whether there is an effect of socioeconomic status, economic rationality on the learning outcomes of students?.

His theoretical study is Robert E. Slavin (2006: 99) "Socioeconomic status (SES), in terms of an individual's income, occupation, education, and prestige in society". Dan Shahram Heshmat (2011: 77) "Socioeconomic status (SES) has traditionally been defined by education, income, race, and rank (occupational status. And Economic Rationality is Trevor J. Barnes
\end{abstract}


(1996: 84) states" Definition of economic rationality, is that in a world of scarce means, but unlimited desires, individuals must make choices ".

The research method used descriptive analysis and regression analysis with the variables of socioeconomic status (X1), and economic rationality (X2). The acquisition of learning outcomes $(\mathrm{Y})$. The population is 630 people. With a sample of 227 students.

Results and Discussion of Regression Analysis: $\mathrm{Y}=71,398+0,544 X_{1}+1,761 X_{2}$

Constant $=71,388$. If the socioeconomic status variable $\left(\mathrm{X}_{1}\right)$ and economic rationality $\left(\mathrm{X}_{2}\right)$ are equal to 0, then the learning outcomes of Pemangkat State Senior High Education students for the 2020/2021 academic year are 71,388.

Conclusion: The socioeconomic status of the partial correlation is $16.6 \%$ with a low level of relationship, the economic rationality of the partial correlation is $48.0 \%$ with a moderate level of relationship, and has an effect on the acquisition of learning outcomes. Likewise, the socioeconomic status and economic rationality of the multiple correlation coefficient were $55.1 \%$ with a moderate level of relationship, and had an effect on the learning outcomes of $30.2 \%$ and the remaining $60.8 \%$ was influenced by other factors.

Keywords: socioeconomic status, economic rationality, learning outcomes

\section{Introduction}

The acquisition of learning outcomes is very necessary because it determines the success of learners for the next step, this is where the role of education is needed to produce qualified graduates. All efforts aimed at developing human potential through the learning process have been done by the school. The process is a noble activity and an ongoing activity.

Education can be considered to have good quality if the knowledge, skills, intelligence and attitude that graduates have can support them in continuing higher education or able to compete in the world of work. To measure the success of education in school is the acquisition of good student learning outcomes, and supported by the role of parents, parental attention to the needs of their children in meeting the needs of their children in meeting learning needs, parents will set aside their financial plans to meet the learning needs of students, with the fulfillment of their child's learning needs, they will be good human beings. 
This is in accordance with the law No. 20 Year 2003 on The National Education System Article 3 that National Education serves to develop the ability and form the character and civilization of a dignified nation in order to educate the life of the nation, aims to develop the potential of learners to become human beings who believe and fear God Almighty, noble, healthy, knowledgeable, capable, creative, independent, and become democratic and responsible citizens.

The school will conduct business consciously and planned so as to realize an atmosphere of learning and an active and creative learning process so that students can develop their potential, obtain strong religious spirituality, self-control, personality, intelligence, noble morals, and skills required by themselves, society, Nation and State.

The success of the students is not only the responsibility of the school, but the responsibility for the family, the community, and the students as well. A good education starts from their own family and residential environment, students' awareness of their financial condition, so that with the limitations of learning facilities, does not make students weak to learn.

The gain of students' learning outcomes is influenced by two factors, namely internal and external factors. Internal factors are factors that come from within the individual, such as an interest in learning, learning, motivation while external factors are external factors that stimulate the occurrence of the teaching and learning process. This factor is influenced by teachers in designing learning, learning atmosphere, family, socioeconomic status, facilities provided to support teaching and learning activities, as well as rational economics of learners, namely understanding consciously the facilities, learning support facilities provided by parents.

The socioeconomic status of parents of learners is very large in determining the achievements of learners, parents who pay attention to educate will certainly always meet their children's learning needs. Such attention can take the form of providing sufficient learning facilities, home learning guidance either done directly or indirectly.

Students must also realize, that the support provided by the family to the child, whether the procurement of learning resources, learning assistance if experiencing difficulties, or the provision of facilities, students can think and act rationally by making the scale of priorities and economic rationality. So it is reflected in the utilization needed.

Economic rationality is rational thinking or acting using common sense in choosing various choices as an attitude that reflects actions that are in accordance with economic principles. By 
acting rationally, students will always think about causality in making a decision in order to fulfill their learning needs. From the attitude of students who perform economic actions, either buying or obtaining the desired learning facilities is really rational in decision making.

High Education Pemangkat is one of the public schools in Jalan Pembangunan Pemangkat subdistrict of Sambas Regency. The total number of students is 630 people, consisting of 18 classes. Class X has 6 study groups totaling 210 students, class XI there are 6 study groups totaling 210 students and class XII there are 6 study groups totaling 210 students.

The parents of the students come from the surrounding community who are heterogeneous from various circles, the level of education type of work. This can be seen from the preliminary data of the study, that most of the education levels of elementary school parents are 85 people, the junior High Education level is 176 people, the High Education level is 289 people, and the college is 100 people. Judging from the work and income of parents of student distribution of family work for civil servants / Polri / TNI for fathers 202 people, private employees about 79 people, self-employed as many as 65 people and farmers / fishermen as many as 284 people

This socioeconomic level of parents can make one try to meet the needs of their children in the field of education, and the child can use the facilities that have been fulfilled by the family by acting economically. The acquisition of student learning results influenced by the recapitulation of the average score of raport Year 2020/2021 obtained during the odd semester of the 2020 / 2021 school year which is 140 students or $22 \%$ of the category is good enough, 441 students or $70 \%$ of good categories, and 49 students or $4 \%$ very good.

Judging from the existing data, researchers are interested in examining whether there is an influence between the socioeconomic status of the family and economic rationality on the acquisition of the learning outcomes of High Education students.

\section{Purpose and objectives of the study}

In this study, we aimed to: know the influence of socioeconomic status on the acquisition of student learning outcomes. The influence of economic rationality on the acquisition of learners' learning outcomes; the influence of socioeconomic status and economic rationality on the acquisition learners' learning outcomes. 


\section{Theoretical Studies}

1. Sadiman (2010) in The Contribution of Parental Attention, Self-Concept And SelfReliance Learning To The Achievement of Learning Productive Subjects Students Class XII Automotive Mechanical Engineering Skills Program SMK Sumarno Colomadu Surakarta can be concluded that :P parental attention, self-concept and self-reliance of learning together have a significant positive contribution with the learning achievements of students of class XII automotive mechanical expertise program SMK Adi Sumarno Colomadu.

2. Nur Hixmah Yulihastuti (2011) with the title: Differences in Economic Learning Achievement Reviewed From The Use of E-Learning Media And Rational Economics Students Grade XI IPS Year 2010 / 2011 (Experimental Study at SMA Negeri 2 Pati) which can be concluded: The learning achievement of students who use e-learning for students with high economic rationale is better than the learning achievement of students with low economic rationale.

3. Harun (2013), The Influence of Learning Motivation and Socioeconomic Background of Parents on The Results of Learning IPS Economics Students of SMP Negeri I Lumar Subdistrict Bengkayang, concluded the background of socioeconomic status of parents of students has a positive and significant effect on the learning outcomes of IPS Economics students grade VIII SMP Negeri 1 Lumar Subdistrict Bengkayang school year 2012/2013.

\section{Theoretical Framework}

\section{Socioeconomic Status}

A person's social status can have a position both morally and materially. The higher one's grief the higher the attention to his child in spelling out the education, because to maintain the position of his family. On the contrary, there is a low social status of a person trying to achieve a better position through the education of his child.

According to John W. Santrock (2007:119) socioeconomic status (SSE) is "Grouping people with similarities of occupation, education, and economic characteristics".

Robert E. Slavin (2006:99) "Socioeconomic status (SES), in terms of an individual's income, occupation, education, and prestige in society". Similarly, Shahram Heshmat (2011:77) "Socioeconomic status (SES) has traditionally been defined by education, income, race, and rank (occupational status)".

Saifullah

Saifi 
(http//misteriyana.wordpress.com/2012/10/07/journal-international-pengaruh-status-socioeconomic-sse-against-achievement-student/). Socioeconomic status (SSE) is "A combined measure of an individual or family's economic or social position relative to others, based on income, education, and employment".

In line with Suparyanto (http://dr-suparyanto.blogspot.com/ 2010/07/konsep-dasar-statusekonomi.html $\quad<$ http://dr-suparyanto.blogspot.com/\%202010/07/concept-basic-statuseconomy.html> states that :Socioeconomic status is the position or position of a person in society, socioeconomic status is a picture of the state of a person or a society that is reviewed in terms of socioeconomic, that picture such as the level of education, income, and so on.

Socioeconomic status is the recognition of conditions in society about income, education, employment, and power possessed by a person that is reviewed in terms of socioeconomic. John W. Santrock (2007:198) suggests there are four main components in socioeconomic position, including:

1) Work with varying prestige

2) Level of educational attainment

3) Economic resources

4) Power level

\section{Economic Rationality}

According to Jerry Kirkpatrick (2007:135) suggests:

Economic rationality means that the ends of action are given (that is, entrepreneurs and consumers do not choose their own goals) and that entrepreneurs and consumers possess perfect rationality (meaning that they cannot make mistakes) and perfect information (they are omniscient).

Trevor J. Barnes (1996:84) states "Definition of economic rationality, is that in a world of scarce means, but unlimited desires, individuals must make choices". While Jean - Paul Chavas (2004:221) "Economic rationality means that economic agents do the best they can to improve their welfare". And Robin L. Bartlett (1997:182) "The definition or assumption of economic rationality means the conquering of spontaneous, erratic, transitory impulses and temptations in the use of scarce resources, or else the lack of impulse control must, in a contradictory fashion, be systematic". 
Dede Nurohman (http://dedenurohman.wordpress.com/2009/ 02/26/ rationality-economicislam/ $\quad<$ http://dedenurohman.wordpress.com/2009/02/26/\%20rasionality-ekonomi-islam/>) states "Economic rationality can be understood as an action on the basis of personal interest (self-interest) to achieve its material satisfaction because of the worry of not getting that satisfaction because of limited tools or sources of gratification". Similarly, Herry Priyono in (www.unisosdem.org/kumtul_detail.php?aid=85\&coid=1\&caid=34\&auid=3) "Economic rationality is a way of thinking, acting on the principle of maximizing profit".

Acting rationally economically is always taken into account the cause and effect in making decisions in order to fulfill their needs so as not to harm themselves, everyone has a diverse need. Weber (2013) type, namely: Zweckrationalitat (Instrumental Rationality) That is the action performed by considering the purpose and tools used to achieve the goal. An action that reflects effectiveness and efficiency.

\section{Learning Outcomes}

a) M. Dimyati and Mudjiono (2013:4) stated that "Learning outcomes are the result of an interaction of learning and teaching".

b) Abu Ahmadi in Sri Habsari (2005:75) stated "Learning achievement is the result achieved in the effort (learning) to make changes or achieve goals".

c) Femi Olivia (2011:73) defines "Learning outcomes are the culmination of learning outcomes that can reflect the results of students' learning success towards a predetermined learning goal".

Student learning achievement is the acquisition of learning outcomes obtained and that appears real to each student in the form of the addition of knowledge, the emergence of new experiences and changes in behavior.

The results obtained by students in terms of calculation of both numbers and letters are a collection of assessments in the teaching and learning process. The final assessment process of learning in the form of determining the value of rapport.

\section{Material and methods}

In this study will describe in detail about the Influence of SocioEconomic Status And Economic Rationality On The Acquisition of Learning Outcomes Learners. Quantitative research is conducted with descriptive analysis that describes the collected data as it is 
without intending to make conclusions that apply to the public or generalization and statistical analysis that is used regression analysis

The population in this study was (1) Students who lived with parents both fathers / biological mother, father and stepmother, (2) Students who lived with guardians, (4) Students who were financed by biological parents / stepmothers / guardians. The population is all students of High Education 2020/2021 school year, which amounts to 630 people. With a sample of 227 students.

Free Variable Research Variables are socioeconomic status (X1), and economic rationality (X2). Bound Variable is the acquisition of learning outcomes (Y).

Data Collection Techniques uses questionnaire instruments or questionnaires that are socioeconomic status questionnaires of parents' 20 items and economic rationality of 26 items using the Likert scale. And for the acquisition of learning outcomes students use report value.

\section{Results and discussion}

Descriptive data, socioeconomic status (X1) results of research that has been carried out as follows: From descriptive statistics on economic status variables (X1) have a maximum value of 108 , while for the minimum value of 67 and has a standard deviation of 8,034 . With the number of samples taken as many as 226 people.

Descriptive data economic rationality (X2) the results of research that has been carried out on rational economic variables (X2) has a maximum value of 107 , while of the minimum value of 67 and has a standard deviation of 9,152. With the number of samples taken as many as 226 people.

Variable Acquisition of learning outcomes (Y) Data on the value of students report odd semester of the 2020/2011 school year can be seen below: Descriptively economic rationality variable data $(\mathrm{X} 2)$ the results of research that has been carried out as follows descriptive statistics on the variable of student learning outcomes (Y) has a maximum value of 87.6341; while for the minimum value of 71.4762 and has a standard deviation of 3.6395227. With the number of samples taken as many as 226 people.

Normality test with Chi Squared Test obtained Chi Squared value (c2) count for family socioeconomic status variable (X1) of 3.16 smaller than the value of Chi Squared (c2) table of 
11,070 then concluded the distribution of statistical value data 226 sample socioeconomic status variable (X1) normal distribution.

Normality test with Kolmogorov-Smirnov Test obtained KSZ value of 1,208 and Asymp.Sigh. 0.107 greater than 0.05 , it can be concluded that the data is normally distributed.

Normality test using a Liliefors normality test, that is, if Liliefors calculate $<$ from Lilifefors table $(\mathrm{L}=0.05)$, then the data are normally distributed, and vice versa if Lilifefors calculates $>$ of Lilifefors table $(\mathrm{L}=0.05)$, then the data is not normally distributed.

The normality test with Liliefors Test obtained a calculated Lilifefors value for the social status variable (X1) against the learning achievement variable (Y) of 0.048; Lilifefors calculates the value of economic rationality variable (X2) against the gain of learning outcomes (Y) of 0.039 ; and the value of Lilifefors calculated for socioeconomic status variable (X1) and economic rationality variable (X2) against learning achievement variable (Y) of 0.038 is less than the table Lilifefors value of 0.059 then concluded the data of family socioeconomic status variable (X1) against learning achievement variable (Y), economic rationality variable (X2) against learning outcome variable (Y) and socioeconomic status variable (X1) and economic rationality variable (X2) against variable learning achievement (Y) is normally distributed.

The normality tests of Chi Squares, Kolmogorov-Smirnov, and Lilifefors conducted above, it can be concluded that the data obtained by researchers in this study either partially or simultaneously produced normally distributed data. Based on the statistical value of Fhitung (Deviation from Linearity) of 0.915 smaller than Ftabel for both error levels of 5\% (1.50) and $1 \%$ (1.79), it can be concluded that socioeconomic status variables (X1) with the acquisition of learning outcomes (Y) have a linear relationship

Obtained statistical value Fhitung of 0.986 smaller than Ftabel both for error level 5\% (1.50) and $1 \%(1.73)$ it can be concluded that between the variables of economic rationality (X2) and the acquisition of learning outcomes $(\mathrm{Y})$ has a linear relationship.

Linearity test results with SPSS Software version 20, then it can be seen the results of the economic rationality variable test (X2) against the variable of learning outcomes (Y) as follows the statistical value of Fhitung (Deviation from Linearity) of 0.984 smaller than Ftabel both for error level 5\% (1.50) and 1\% (1.73) it can be concluded that between the variable economic rationality $(\mathrm{X} 2)$ with learning results $(\mathrm{Y})$ has a linear relationship. 
Regression Analysis shows the regression equation obtained from the results of the analysis, namely:

The similarity of regression in this study has the following meanings:

Constant $=71,388$. If the variable socioeconomic status (X1) and economic rationality (X2) is equal to 0, then the learning outcomes of the students of High Education Pemangkat Tahun 2020/2021 are 71,388.

Coefficient $\mathrm{X} 1=0.543$. If the variable condition of socioeconomic status (X1) increases by 1 point while the variable of economic rationality (X2) is considered fixed, it will lead to an increase in the learning outcomes of students at High Education Pemangkat, years sturdy $2020 / 2021$ by 0.543 .

Coefficient $\mathrm{X} 2=1.757$. If the variable condition of economic rationality (X2) increases by 1 point while the family socioeconomic status variable (X1) is considered fixed, it will lead to an increase in the learning outcomes of students at High Education Pemangkat, years sturdy $2020 / 2021$ of 1,757 .

To determine the meaning of this regression equation by comparing Fcalculate with Ftabel. Based on the table above obtained the value of Fcalculate of 89,459 with. Furthermore $F_{\text {calculate }}$ can be compared with Ftabel with df numerator $=k-1$ and $d k$ denominator $=n-2$, then the value of Ftabel with df numerator $=1$ and df denominator $=225$ with an error rate of $5 \%$ is 3.86. Inferred coefficient of regression means.

Data processing obtained a value of $\mathrm{R}=0.552$, it can be stated that the coefficient of double correlation in this study is 0.552 . When compared to the table of correlation coefficient interpretation, the double correlation coefficient value of 0.552 has a moderate level of relationship/influence between $\mathrm{X}$ and $\mathrm{Y}$. To determine the magnitude of the contribution of a free variable to a bound variable using a determination coefficient. Value R2 (R Square) = 0.304 . With these results, it can be stated that the coefficient of determination is as follows: $30.4 \%$

The result of the coefficient of determination showed 30.4\%, meaning that showing socioeconomic status and economic rationality to the acquisition of learning outcomes in the $2020 / 2021$ school year amounted to $30.2 \%$ of the remaining $60.8 \%$ of the learning outcomes were influenced by other factors not studied in this study. 
Based on the results of the calculation obtained correlation together (simultaneously) of 0.308 means there is a low relationship between the variable socioeconomic status (X1) and economic rationality (X2) to the acquisition of learning outcomes (Y). While the relationship of socioeconomic status variables (X1) with the acquisition of learning outcomes (Y) partially has a correlation coefficient of 0.164 and the relationship between economic rationality variables (X2) and the acquisition of learning outcomes (Y) partially has a correlation coefficient of 0.480 . This suggests that both variables partially have a low relationship with the learning outcomes of the learners.

The calculation obtained $t_{\text {analitic }}$ for socioeconomic status variable (X1) of 2,511 and variable

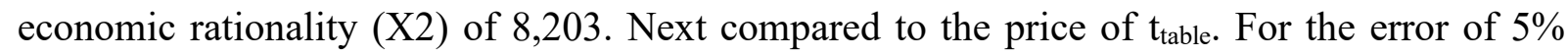
test two parties with $\mathrm{dk}=\mathrm{n}-2$, then obtained table of 1.96 and it turns out that the price of $t_{\text {analitic }}$ is greater than the $t_{\text {table, }}$ this means there is a relationship between the variable socioeconomic status to the acquisition of the learning outcomes of High Education year $2020 / 2021$ and there is a relationship between the variables of economic rationality to the acquisition of learning outcomes of High Education students year 2020/2021.

The results of statistical tests that have been conducted obtained a Fhitung score of 49,005 > Ftabel with a $5 \%$ error rate of 3.86 , this means Ho was rejected, then there is a significant positive influence between socioeconomic status and economic rationality with the learning achievements of High Education students.

\section{Conclusion}

1. Socioeconomic status of partial correlation is $16.6 \%$ with a very low level of interpretation relationship, and has a positive and significant effect on the learning outcomes of High Education students in the 2020/2021 school year.

2. Economic rationality obtained a partial correlation coefficient value of $48.0 \%$ with a moderate level of interpretation relationship, and had a positive and significant effect on the acquisition of learning outcomes of High Education students in the 2020/2021 school year.

3. Simultaneously socioeconomic status and economic rationality obtained a double correlation coefficient value of 55.1\% with a moderate level of interpretation relationship, and positively and significantly influenced the learning outcomes of High Education students in the 2020/2021 school year. The percentage influence of socioeconomic status and economic 
rationality on the gain of learners' learning outcomes by $30.2 \%$ and the remaining $60.8 \%$ was influenced by other factors not studied in this study.

\section{References}

[1] Abdulsyani. (2012). Sociology of Schematics, Theory and Applied. (Fourth Printing). Jakarta : Bumi Aksara.

[2] Abu Ahmadi. (2007). Basic Social Sciences. Jakarta : Rineka Cipta.

[3] Damsar. Indrayani. (2013). Introduction to Economic Sociology. (Second Edition. Third Printing). Jakarta : Kencana.

[4] Femi Olivia. (2011). Tools For Study Skills. Effective Exam Techniques. Jakarta : PT. Elex Media Komputindo.

[5] Jean-Paul Chavas. (2014). Risk Analysis In Theory And Practice. United States of America : Academic Press Publications.

[6] Jerry Kirkpatrick. (2007). In Defense Of Advertising. United States of America : Quorum Books, an imprint of Greenwood Publishing Group, Westport, CT.

[7] John W. Santrock. (2007). Teen. (Translation Edition By Shinto B. Adelar; Sherly Saragih). Jakarta : Erlangga.

[8] M. Dawam Rahardjo. (1993). Perspective of the Declaration of Makkah. Towards Islamic Economics. First Printing. Bandung : Mizan.

[9] N. Gregory Mankiw. (2012). Economic Principles. Sixth Edition. Canada : Nelson Education, Ltd.

[10] Robert E. Slavin. (2006). Educational Psychology. Theory And Practice. Eighth Edition. United States of America : Pearson Education.

[11] Robin. L. Bartlett. (1997). Introducting Race And Gender Into Economics. London : Routledge.

[12] S.C. Bloch. (2007). Excel For Engineers and Scientists. (Second Edition). Jakarta : Erlangga.

[13] Shahram Heshmat. (2011). Eating Behavior And Obesity. Behavioral Economics Strategies For Health Professionals. New York : Springer Publishing Company.

[14] Singgih Santoso. (2019). Parametric Statistics. Concepts and Applications with SPSS. (Revised Edition). Jakarta : PT. Elex Media Komputindo.

[15] Slameto. (2013). Learning and Influencing Factors. Jakarta : Rineka Cipta. 
[16] Trevor J. Barnes. (1996). Logics Of Dislocation. Models, Metaphors, and Meanings of Economic Space. New York USA : The Guilford Press.

[17] Law of the Republic of Indonesia No. 20 of 2003. (2011). National Education System. (Fourth printing). Jakarta : Sinar Grafika Offset.

[18] Law of the Republic of Indonesia No.23 of 2002. Child Protection.

[19] Aaron. (2013). The Influence of Learning Motivation and Socioeconomic Background of Parents on The Results of Learning IPS Economics Students of SMP Negeri I Lumar Subdistrict Bengkayang. Pontianak : University of Tanjungpura.

[20] Nur Hixmah Yulihastuti. (2011). Differences in Economic Learning Achievements Reviewed From The Use of E-Learning Media And Student Learning Activities Grade XI IPS Year 2010 / 2011 (Experimental Study at SMA Negeri 2 Pati). Surakarta : University of Eleven March.

[21] Sadiman. (2010). Contribution of Parental Attention, Self-Concept And Self-Reliance Of Learning To The Achievement of Productive Subjects Students Class XII Automotive Mechanical Engineering Skills Program SMK Sumarno Colomadu Surakarta. Surakarta : University of Eleven March.

[22] Dede Nurohman. Islamic Economic Rationality. http://dedenurohman. wordpress.com/2009/02/26/rasionalitas-ekonomi-islam/ $<$ http://dedenurohman.wordpress.com/2009/02/26/rasionalitas-ekonomi-islam/> downloaded on $06 / 04 / 2014$.

[23] Herry Priyono. KKN Is Not a Culture. http://www.unisosdem.org/ kumtul_detail.php?aid=85\&coid=1\&caid=34\&auid=3

$<$ http://www.unisosdem.org/kumtul_detail.php?aid=85\&coid=1\&caid=34\&auid=3> downloaded on $06 / 04 / 2014$.

[24] Saifullah Saifi. Effect of Socioeconomic status on Student Achievement. $<$ http://misteriyana.wordpress.com/2012/10/07/journal-internasional-pengaruh-statussosial-ekonomi-sse-terhadap-prestasi-siswa/> downloaded on 31/03/2020.

[25] Suparyanto. Basic Concept of Economic Status. http://dr-suparyanto.blogspot.com/ 2010/07/konsep-dasar-status-ekonomi.html $<\mathrm{http}: / / \mathrm{dr}-$ suparyanto.blogspot.com/\%202010/07/konsep-dasar-status-ekonomi.html> downloaded on March 31, 2020. 
[26] Melman S., Ashby S., James Carole. Supervision in Practice Education and Transition to Practice: Student and New Graduate Perceptions. Internet Journal of Allied Health Sciences and Practice. Volume 14.Number 3. Article 1. July 2016. 1-16

[27] Ordinance for unified state requirements for the specialties of the professional field "Health care" to a Professional Bachelor degree, State Gazette, 87, 2008.

[28] Ordinance 1/8.02.2011 for professional activities that nurses, midwives, associated medical specialists and healthcare assistants may perform on prescription or on their own. State Gazette, No 15/18.02.2011.

[29] Panteva, Ts., Potential of modern medical rehabilitation and ergotherapy. Kinesitherapy and Rehabilitation, 2007, 6, 1-2, 44-51.

[30] Paskaleva, R., Effect of contemporary elements of the training in kinesitherapy, art therapy and occupational therapy on professional skills of graduating rehabilitation specialists at the Medical College - Stara Zagora, PhD Thesis, 2012, Stara Zagora, 9-37.

[31] Paskaleva, R., Application of art therapy and occupational therapy in the practical training of students majoring in Rehabilitation at the Medical College - Stara Zagora, Prevention and Rehabilitation, 2011; 5(2): 36-41.

[32] Paskaleva, R., Co-operation and participation of students majoring in Rehabilitation during the pre-graduation internship. Health Care, 2011; 4: 17- 23.

[33] Paskaleva, R., The role of the mentor for formation of professional skills of Rehabilitation students during the pre-graduation internship. Nursing , 2012;1: 23-27.

[34] Popov, T. Therapy and prophylaxis with art, Sofia, Education Publishing, 2004.

[35] Popov, T. Again about dancing , Sofia, Education Publishing,, 2005.

[36] Popov, T. Art therapy in children, Sofia, Defecto Publishing, 2008.

[37] PHARE programme - Economic and Social Cohesion, Project BG 0202.01, Clearing the path to employment for youths - grant scheme for initiatives for youth employment.

[38] Stoyanova D. Investigation of the level of academic motivation of students from paedagogical majors. Scientific Works of the University of Rousse,2009; vol 48, series $6.2 ; 184-189$.

[39] Turnyova B., T. Cherkezov. Motivation for training of students majoring in Health Care Management in conditions of continuing education. Management and Education, 2009, vol $\mathrm{V},(3), 100-104$.

[40] Williams, K., \& Williams, C. (2011). Five key ingredients for improving motivation. Research in Higher Education Journal, 1-23. 